\title{
FAKTOR PREDISPOSISI YANG MEMPENGARUHI KEBERHASILAN PEMBERIAN ASI EKSKLUSIF BERDASARKAN TEORI MATERNAL ROLE ATTAINMENT RAMONA T MERCER
}

\author{
Dwi Rahayu $^{1 *}$, Yunarsih ${ }^{2}$ \\ ${ }^{1,2}$ Akademi Keperawatan Dharma Husada Kediri \\ *Corresponding author: alfarezapriyoputra@yahoo.com
}

\begin{abstract}
According to the Indonesian Demographic Health Survey (SDKI) from 1997 to 2002, the number of exclusive breastfeeding infants aged six months decreased from $7.9 \%$ to 7.8\%. Meanwhile, the results of SDKI 2007 showed decreased number of exclusively breastfeeding infants up to $7.2 \%$ and the number of infants under six months who fed formula improved from 16.7\% in 2002 to 27.9\% in 2007. The number of infants in Indonesia who get exclusive breastfeeding continues to decline as more and more babies under 6 months of formula-feeding. The purpose of this research was to determine the factors that affect the successfull of exclusive breastfeeding Based On Maternal Role Attainment Ramona T Mercer Theory. The type of this research is an analytic survey. The population in this study are mothers who have babies aged 0-6 months in the Village Pojok Kediri. Sampling technique by Purposive Sampling and obtained the number of samples are 30 Respondents. The instrument used in this study is a questionnaire. Data analysis using Chi-Square test with $\alpha=0,05$. From the results of this study it was found that factors related to exclusive breastfeeding practices were maternal education ( $p$ value: 0,037), information how to breastfeeding ( $p$ value: 0,031), and community support ( $p$ value: 0,010), while Factors not related to Exclusive Breastfeeding practices include age ( $p$ value: 0.293), occupation ( $p$ value: 0.297), information of exclusive breastfeeding ( $p$ value: 0,903), Family Support ( $p$ value: 0.479) and Health Workers's Support ( $p$ value: 0.669) . To improve the success of exclusive breastfeeding, counseling should be started from antenatal visit of the Pregnant Woman that aims to provide information preparation for breastfeeding, and counseling will be continued during breastfeeding which aims to monitor Exclusive breastfeeding up to 6 months and increase the participation of parents in exclusive breastfeeding support groups.
\end{abstract}

\section{Keywords: Predisposing Factor, Exclusive Breastfeeding}

\section{PENDAHULUAN}

Air Susu Ibu (ASI) merupakan makanan yang paling direkomendasikan untuk bayi sedikitnya pada 6 bulan pertama kehidupan (Kramer \& Kakuma, 2002). Ketidakcukupan produksi ASI merupakan alasan utama seorang ibu untuk penghentian pemberian ASI secara dini, ibu merasa dirinya tidak mempunyai kecukupan produksi ASI untuk memenuhi kebutuhan bayi dan mendukung kenaikan berat badan bayi yang adekuat (Binns, 2002), sehingga hal tersebut menjadikan menyusui merupakan hal yang dapat menimbulkan stress bagi seorang ibu post partum (Anamed, 2012).

Menurut Survei Demografi Kesehatan Indonesia (SDKI) dari 1997 hingga 2002, jumlah bayi usia enam bulan yang mendapatkan ASI eksklusif menurun dari $7,9 \%$ menjadi $7,8 \%$. Sementara itu, hasil SDKI 2007 menunjukkan penurunan jumlah bayi yang mendapatkan ASI eksklusif hingga $7,2 \%$ dan jumlah bayi di bawah enam bulan yang diberi susu formula meningkat dari $16,7 \%$ pada 2002 menjadi $27,9 \%$ pada 2007 . Jumlah bayi di Indonesia yang mendapatkan ASI eksklusif 
terus menurun karena semakin banyaknya bayi di bawah 6 bulan yang diberi susu formula (Sutama, 2008).

Rendahnya pemberian ASI eksklusif karena para ibu belum mengetahui manfaat ASI bagi kesehatan anak. Dukungan dari ayah juga mempengaruhi keberhasilan pemberian ASI eksklusif selama enam bulan. Keputusan ibu untuk menyusui dipengaruhi informasi anggota keluarga tentang manfaat menyusui, serta konsultan laktasi (Wulandari, 2009).

Menyusui merupakan salah satu proses adaptasi yang dialami ibu postpartum, yaitu perode 24 jam setelah melahirkan hingga 6 minggu. Saat terpenting waktu menyusui adalah beberapa hari pertama setelah melahirkan. Bila seorang ibu dibantu dengan baik pada saat ia mulai menyusui, kemungkinan ibu tersebut akan berhasil untuk terus menyusui (Siregar A, 2004). Sebenarnya, menyusui khususnya secara eksklusif merupakan cara pemberian makanan bayi yang alamiah. Namun, seringkali ibu-ibu kurang mendapatkan informasi bahkan seringkali salah tentang manfaat ASI eksklusif, tentang bagaimana cara menyusui yang benar, dan apa yang harus dilakukan bila timbul kesukaran dalam menyusui bayinya (Utami Roesli, 2007). Seiring dengan perkembangan jaman, terjadi pula peningkatan ilmu pengetahuan dan teknologi yang demikian pesat. Ironinya, pengetahuan lama yang mendasar seperti menyusui justru terlupakan (Utami Roesli, 2000). Di dalam denyut kehidupan kota besar, kita lebih sering melihat bayi diberi susu botol daripada disusui oleh ibunya. Sementara di pedesaan, kita melihat bayi yang baru berusia satu bulan sudah diberi pisang atau nasi halus sebagai tambahan ASI.

Ikatan Dokter Anak Indonesia (IDAI) tahun 2013 menyatakan bahwa dalam kenyataannya, pemberian ASI eksklusif selama enam bulan pertama kehidupan bayi memiliki banyak kendala, seperti ibu kurang memahami tata laksana laktasi yang benar, ibu bekerja, dan produksi ASI yang kurang. Beberapa faktor diduga menyebabkan berkurangnya produksi ASI, yaitu faktor menyusui, faktor psikologis ibu, faktor fisik ibu, dan faktor bayi. Faktor psikologis seperti stres, khawatir, ketidakbahagiaan ibu pada periode menyusui sangat berperan dalam menyukseskan pemberian ASI eksklusif (IDAI, 2013).

Dampak dari tidak diberikannya ASI secara eksklusif bisa menurunkan daya tahan tubuh sehingga bayi rentan infeksi terutama gangguan pada sistem pencernaan. Untuk menunjang keberhasilan program pemberian ASI eksklusif dengan mengingat bahwa pemberian ASI eksklusif sangat penting dalam tumbuh kembang bayi, maka perlu sekali dilakukan penelitian tentang Faktor - Faktor Yang Mempengaruhi Keberhasilan Pemberian ASI Eksklusif Pendekatan Maternal Role Attainment Ramona T Mercer

\section{METODE PENELITIAN}

Jenis penelitian ini adalah survei analitik dengan pendekatan crosssectional. Variabel terikat (dependent variable) pada penelitian ini adalah keberhasilan pemberian ASI eksklusif. Sedangkan variabel bebas (independent variable) pada penelitian ini terdiri dari umur, pendidikan,pekerjaan, pengetahuan, peran petugas, keterpaparan informasi, dukungan keluarga, dukungan masyarakat. Populasi dalam penelitian ini adalah ibu-ibu yang mempunyai bayi usia 0-6 bulan yang ada di Kelurahan Pojok Kota Kediri. Teknik pengambilan sampel dengan cara Purposive Sampling dan didapatkan jumlah sampel sebesar 30 Responden. Instrumen yang digunakan dalam penelitian ini adalah kuesioner. Analisis data menggunakan uji Chi-Square dengan $\alpha=$ 0,05 . Apabila didapatkan hasil $\mathrm{p}$ value $<\alpha$ berarti ada hubungan yang signifikan antara variabel bebas dengan variabel terikat. 


\section{HASIL PENELITIAN}

Dari penelitian yang telah dilakukan diperoleh hasil sebagai berikut:

Tabel 1. Data Demografi Responden dan Praktik Pemberian ASI Eksklusif

\begin{tabular}{|c|c|c|c|c|c|c|c|}
\hline $\begin{array}{l}\mathrm{N} \\
\mathrm{o}\end{array}$ & $\begin{array}{l}\text { Karakt } \\
\text { eristik }\end{array}$ & $\begin{array}{c}\text { Fre } \\
\text { kue } \\
\text { nsi } \\
\end{array}$ & $\begin{array}{l}\text { Prose } \\
\text { ntase }\end{array}$ & $\begin{array}{c}\text { ASI } \\
\text { Ekskl } \\
\text { usif } \\
\end{array}$ & $\begin{array}{c}\text { ASI } \\
\text { Predom } \\
\text { inan } \\
\end{array}$ & $\begin{array}{l}\text { Non } \\
\text { ASI }\end{array}$ & $\begin{array}{c}\text { Nilai } \\
\mathrm{p}\end{array}$ \\
\hline \multirow[t]{4}{*}{1} & Usia & & & & & & \\
\hline & $\begin{array}{l}<20 \\
\text { tahun }\end{array}$ & 1 & $4 \%$ & $0 \%$ & $\begin{array}{c}1(100 \% \\
)\end{array}$ & $0 \%$ & \multirow{3}{*}{$\begin{array}{c}\mathrm{p}: \\
0,293\end{array}$} \\
\hline & $\begin{array}{l}20-35 \\
\text { tahun }\end{array}$ & 22 & $73 \%$ & $\begin{array}{l}10(45 \\
, 5 \%)\end{array}$ & $\begin{array}{c}5(22,7 \\
\%)\end{array}$ & $\begin{array}{c}7(31,8 \\
\%)\end{array}$ & \\
\hline & $\begin{array}{l}>35 \\
\text { tahun }\end{array}$ & 7 & $23 \%$ & $\begin{array}{c}2(28, \\
6 \%)\end{array}$ & $\begin{array}{c}4(57,1 \\
\%)\end{array}$ & $\begin{array}{c}1(14,3 \\
\%)\end{array}$ & \\
\hline \multirow[t]{5}{*}{2} & \multicolumn{6}{|c|}{ Pendidikan } & \multirow{5}{*}{$\begin{array}{c}\mathrm{p}: \\
0,037\end{array}$} \\
\hline & $\mathrm{SD}$ & 4 & $14 \%$ & $\begin{array}{c}1(25 \\
\%)\end{array}$ & 0 & $3(75 \%)$ & \\
\hline & SMP & 9 & $30 \%$ & $\begin{array}{l}2(22, \\
2 \%)\end{array}$ & $\begin{array}{c}6(66,7 \\
\%)\end{array}$ & $\begin{array}{c}1(11,1 \\
\%)\end{array}$ & \\
\hline & $\begin{array}{l}\text { SMA/S } \\
\text { MK }\end{array}$ & 13 & $43 \%$ & $\begin{array}{c}8(61, \\
5 \%)\end{array}$ & $1(7,6 \%)$ & $\begin{array}{c}4(30,9 \\
\%)\end{array}$ & \\
\hline & $\begin{array}{l}\text { Pergur } \\
\text { uan } \\
\text { Tinggi }\end{array}$ & 4 & $14 \%$ & $\begin{array}{c}1(25 \\
\%)\end{array}$ & $3(75 \%)$ & 0 & \\
\hline \multirow[t]{3}{*}{3} & Pekerja & & & & & & \multirow{3}{*}{$\begin{array}{c}p: \\
0,297\end{array}$} \\
\hline & $\begin{array}{l}\text { Bekerj } \\
\mathrm{a}\end{array}$ & 9 & $30 \%$ & $\begin{array}{c}5(55, \\
6 \%) \\
\end{array}$ & $\begin{array}{c}2(22,2 \\
\%)\end{array}$ & $\begin{array}{c}2(22,2 \\
\%) \\
\end{array}$ & \\
\hline & $\begin{array}{l}\text { Ibu } \\
\text { Rumah } \\
\text { Tangga }\end{array}$ & 21 & $70 \%$ & $\begin{array}{c}7 \\
(33,3 \\
\%) \\
\end{array}$ & $\begin{array}{c}8 \\
(38,1 \%)\end{array}$ & $\begin{array}{c}6 \\
(28,6 \% \\
)\end{array}$ & \\
\hline \multirow[t]{3}{*}{4} & \multicolumn{6}{|c|}{ Informasi tentang ASI Eksklusif } & \multirow{3}{*}{$\begin{array}{c}\mathrm{p}: \\
0,903\end{array}$} \\
\hline & $\mathrm{Ya}$ & 13 & $43 \%$ & $\begin{array}{c}5(38, \\
6 \%) \\
\end{array}$ & $\begin{array}{c}4(30,7 \\
\%) \\
\end{array}$ & $\begin{array}{c}4(30,7 \\
\%)\end{array}$ & \\
\hline & Tidak & 17 & $57 \%$ & $\begin{array}{l}7(41, \\
2 \%)\end{array}$ & $\begin{array}{c}6(35,3 \\
\%)\end{array}$ & $\begin{array}{c}4(23,5 \\
\%)\end{array}$ & \\
\hline \multirow[t]{3}{*}{5} & \multicolumn{6}{|c|}{ Informasi tentang Cara Menyusui } & \multirow{3}{*}{$\begin{array}{c}\mathrm{p}: \\
0,031\end{array}$} \\
\hline & $\mathrm{Ya}$ & 4 & $14 \%$ & $\begin{array}{c}4(100 \\
\%)\end{array}$ & 0 & 0 & \\
\hline & Tidak & 26 & $86 \%$ & $\begin{array}{l}8(30, \\
7 \%)\end{array}$ & $\begin{array}{c}10(38,6 \\
\%)\end{array}$ & $\begin{array}{c}8(30,7 \\
\%)\end{array}$ & \\
\hline \multirow[t]{3}{*}{6} & \multicolumn{6}{|c|}{ Dukungan Keluarga } & \multirow{3}{*}{$\begin{array}{c}\mathrm{p}: \\
0,479\end{array}$} \\
\hline & $\mathrm{Ya}$ & 28 & $93 \%$ & $\begin{array}{c}12(42 \\
, 9 \%)\end{array}$ & $\begin{array}{c}9(32,1 \\
\%)\end{array}$ & $7(25 \%)$ & \\
\hline & Tidak & 2 & $7 \%$ & 0 & $1(50 \%)$ & $1(50 \%)$ & \\
\hline \multirow[t]{3}{*}{7} & \multicolumn{6}{|c|}{ Dukungan Petugas Kesehatan } & \multirow{3}{*}{$\begin{array}{c}\mathrm{p}: \\
0,669\end{array}$} \\
\hline & $\mathrm{Ya}$ & 28 & $93 \%$ & $\begin{array}{c}11(39 \\
, 3 \%) \\
\end{array}$ & $\begin{array}{c}9(32,1 \\
\%) \\
\end{array}$ & $\begin{array}{c}8(28,6 \\
\%)\end{array}$ & \\
\hline & Tidak & 2 & $7 \%$ & 1 & 1 & 0 & \\
\hline \multirow[t]{3}{*}{8} & Dukung & n Ma & arakat & & & & \\
\hline & $\mathrm{Ya}$ & 27 & $90 \%$ & $\begin{array}{c}12(44 \\
, 4 \%) \\
\end{array}$ & $\begin{array}{c}10(37 \% \\
)\end{array}$ & $\begin{array}{c}5(18,6 \\
\%)\end{array}$ & \multirow[t]{2}{*}{$\begin{array}{c}\mathrm{p}: \\
0,010\end{array}$} \\
\hline & Tidak & 3 & $10 \%$ & 0 & 0 & $\begin{array}{c}3(100 \\
\%)\end{array}$ & \\
\hline
\end{tabular}

Berdasarkan tabel diatas sebagaian besar responden (73\%) berusia 20-35 Tahun dan dari hasil uji statistik didapatkan $\mathrm{p}$ value $=$ 0,293 , dimana $\mathrm{p}>0,05$ berarti tidak ada hubungan yang signifikan antara usia ibu dengan praktik pemberian ASI Eksklusif.
Hasil penelitian untuk faktor pendidikan didapatkan hampir setengah responden (43\%) berpendidikan SMA/SMK, dan hasil uji statistik didapatkan $\mathrm{p}$ value $=0,037$, dimana $\mathrm{p}<0,05$ berarti terdapat hubungan yang signifikan antara pendidikan dengan praktik pemberian ASI Eksklusif.

Dari Hasil penelitian didapatkan sebagian besar responden (70\%) bekerja sebagai Ibu Rumah tangga, sedangkan untuk praktik pemberian ASI Eksklusif hanya terdapat 33,3\% Responden yang berhasil memberikan ASI Eksklusif, dan dari hasil uji statistik didapatkan $\mathrm{p}$ value : 0,297 dimana $p>0,05$ yang berarti tidak terdapat hubungan yang signifikan antara faktor pekerjaan dan Praktik Pemberian ASI Eksklusif. Faktor Keterpaparan Responden terhadap informasi tentang ASI Eksklusif didapatkan $57 \%$ responden tidak terpapar dengan informasi Pemberian ASI Eksklusif dan dan hasil uji statistik didapatkan $p$ value : 0,903 dimana $p>0,05$ yang berarti tidak ada hubungan antara informasi tentang pemberian ASI Eksklusif dengan Praktik Pemberian ASI Eksklusif. Dari faktor informasi tentang cara menyusui didapatkan hasil sebanyak $14 \%$ responden yang mendapatkan informasi tentang cara menyusui dan $100 \%$ responden yang mendapatkan informasi berhasil memberikan ASI Eksklusif dan dari hasil statistik didapatkan $p$ value : 0,031 dimana $p<0,05$ dan terdapat hubungan yang signifikan antara informasi tentang cara menyusui dan praktik pemberian ASI Eksklusif. Faktor dukungan keluarga dan dukungan dari petugas kesehatan didapatkan hasil hampir seluruh responden (93\%) mendapatkan dukungan yang positif dan dilihat dari hasil uji statistik didapatkan Dukungan Keluarga ( $p$ value : 0,479), serta Dukungan dari Petugas Kesehatan ( $p$ value: 0,669), dimana p>0,05 berarti tidak ada hubungan yang signifikan antara dukungan keluarga ataupun dukungan petugas kesehatan dengan praktik pemberian ASI Eksklusif. Faktor Dukungan masyarakat didapatkan hampir seluruh responden (90\%) 
mendapatkan dukungan yang baik dari anggota masyarakat sekitar, dan dari hasil uji statistik didapatkan $\mathrm{p}$ value: 0,010 , dimana $\mathrm{p}<0,05$ yang berarti terdapat hubungan yang signifikan antara informasi tentang cara menyusui dan praktik pemberian ASI Eksklusif.

\section{PEMBAHASAN}

Dari hasil penelitian ini didapatkan bahwa faktor-faktor yang ada hubungan dengan praktik pemberian ASI eksklusif adalah pendidikan ibu ( $p$ value : 0,037), informasi tentang cara menyusui ( $p$ value: $0,031)$, serta dukungan dari masyarakat ( $p$ value : 0,010). Hasil penelitian untuk faktor pendidikan didapatkan hampir setengan responden $(43 \%)$ berpendidikan SMA/SMK, dan hasil uji statistik didapatkan $\mathrm{p}$ value $=$ 0,037, dimana $p<0,05$ berarti terdapat hubungan yang signifikan antara pendidikan dengan praktik pemberian ASI Eksklusif. Pendidikan merupakan salah satu faktor yang secara tidak langsung mempengaruhi laktasi terkait dengan latar belakang sosial budaya. Hal ini berkaitan dengan kemampuan ibu untuk menerima informasi yang nantinya berpengaruh secara langsung dalam proses pengeluaran ASI. Faktor langsung yang terkait psikologis ibu meliputi persepsi ibu mengenai keuntungan dan kerugian menyusui dan pengetahuan tentang menyusui (Biancuzzo, 2003). Pendidikan dapat mempengaruhi seseorang akan pola hidup terutama dalam pembangunan kesehatan. Makin tinggi pendidikan seseorang makin mudah menerima informasi sehingga makin banyak pula pengetahuan yang dimiliki (nursalam, 2001). Dengan pendidikan tersebut responden akan lebih mudah menerima informasi sehingga makin banyak pula pengetahuan yang dimiliki disebabkan oleh pengalaman yang dipunyai oleh responden. Pengalaman merupakan salah satu faktor dari terbentuknya pengetahuan. Pendidikan merupakan kebutuhan dasar manusia yang sangat dibutuhkan untuk pengembangan diri. Semakin tinggi tingkat pendidikan semakin mudah menerima serta mengembangkan pengetahuan dan tehnologi juga semakin meningkatnya produktivitas serta semakin tinggi kesejahteraan keluarganya. Pendidikan ibu berpengaruh terhadap Praktik Pemberian ASI eksklusif. Ibu yang berpendidikan tinggi akan lebih baik penerimaannya terhadap ASI eksklusif serta lebih berupaya untuk mempraktikannya. Penyerapan informasi yang beragam dan berbeda dipengaruhi oleh tingkat pendidikan. Pendidikan akan berpengaruh pada seluruh aspek kehidupan manusia baik pikiran, perasaan maupun sikapnya (Sandra, 2010). Semakin tinggi tingkat pendidikan semakin tinggi pula kemampuan dasar yang dimiliki seseorang, khususnya pemberian ASI. Tingkat pendidikan dapat mendasari sikap ibu dalam menyerap dan mengubah sistem informasi tentang ASI (Isna, 2008).

Dari faktor informasi tentang cara menyusui didapatkan hasil sebanyak $14 \%$ responden yang mendapatkan informasi tentang cara menyusui dan $100 \%$ responden yang mendapatkan informasi berhasil memberikan ASI Eksklusif dan dari hasil statistik didapatkan $p$ value : 0,031 dimana $\mathrm{p}<0,05$ dan terdapat hubungan yang signifikan antara informasi tentang cara menyusui dan praktik pemberian ASI Eksklusif Pengetahuan merupakan domain yang sangat penting untuk tindakan seseorang. Perilaku yang didasari oleh pengetahuan akan lebih baik dari pada perilaku yang tidak didasari pengetahuan.

Dukungan masyarakat berhubungan dengan keberhasilan pemberian ASI Eksklusif, didapatkan $p$ value : 0,010. Berdasarkan hasil penelitian didapatkan hampir seluruh responden (90\%) mendapatkan dukungan yang baik dari masyarakat. Masyarakat dalam hal ini termasuk tetangga sekitar lingkungan rumah responden. Praktek pemberian ASI juga diketahui oleh budaya dan norma yang berkembang di kalangan anggota keluarga, rekan dan masyarakat secara umum. Peranan budaya dan masyarakat terhadap berhasil tidaknya ibu memberikan ASI 
eksklusif sangat besar. Kebiasaan masyarakat masih terdapat budaya pemberian MP-ASI dini pada bayi. Walaupun ibu mengetahui bahwa pemberian MP ASI terlalu dini dapat menyebabkan ganggguan pada kesehatan bayi, namun mereka beranggapan bahwa bayi jika bayi tidak mengalami gangguan maka pemberian MP-ASI dini dapat dilanjutkan. Selain Itu kebiasaan memberikan MP ASI dini telah dilakukan turun temurun dan tidak pernah menimbulkan masalah. Dukungan masyarakat sekitar merupakan faktor eksternal yang paling besar pengaruhnya terhadap ASI eksklusif, karena dukungan masyarakat sekitar sangat besar pengaruhnya terhadap rasa percaya diri ibu. Bila ibu yang menyusui mengalami stress, maka akan terjadi suatu blokade dari refleks let down. Ini disebabkan oleh karena ada pelepasan dari adrenalin (epinefrin) yang menyebabkan vasokonstriksi dari pembuluh darah alveoli, sehingga oksitosin yang dapat mencapai target organ mioepitelium hanya sedikit. Selain itu akan terjadi pula pelepasan noradrenalin pada sistem syaraf pusat sehingga aktivitas kedua substansi kimia ini akan menyebabkan terhambatnya milk ejection reflex (Riordan \& Auerbach, 2010). Refleks let down yang tidak sempurna akan berakibat bayi yang haus menjadi tidak puas. Ketidakpuasan ini akan menyebabkan tambahan stress bagi ibu. Bayi yang haus dan tidak puas ini akan berusaha untuk mendapatkan air susu yang cukup dengan cara menambah kuat hisapannya sehingga tidak jarang menimbulkan luka-luka pada puting susu yang menyebabkan rasa sakit pada ibu. Hal ini juga akan menambah stress pada ibu sehingga akan terbentuk suatu lingkaran setan (circulus vitiosus) dengan akibat kegagalan dalam menyusui (Machfuddin, 2004) dan proses pemberian ASI Eksklusif gagal dilakukan.

Sesuai dengan teori bahwa prolaktin yang dihasilkan selama proses menyusui telah diteliti mempunyai efek relaksasi yang menyebabkan ibu menyusui merasa tenang bahkan mempunyai efek euforia sehingga semakin tinggi kadar prolaktin, dapat mencegah kejadian postpartum blues (Riordan\&Auerbach, 2010). Menyusui juga melindungi Ibu dengan menginduksi ketenangan, mengurangi reaktivitas ibu untuk stress. Menyusui memiliki efek perlindungan pada kesehatan mental ibu yang disebabkan karena stress dengan cara melemahkan dan memodulasi respon inflamasi melalui penurunan kortisol, ACTH, epinefrin dan norepinefrin. Ketika menyusui berjalan dengan baik, kadar proinflammatory cytokine akan turun dalam batas normal sehingga menurunkan reaksi inflamasi yang menjadi underlying risk factor terjadinya depresi, hal ini akan melindungi ibu dari stress dan menjaga suasana hati ibu (Tackett, 2007).

Dari Hasil Penelitian, faktor - faktor yang tidak berhubungan dengan praktik pemberian ASI Eksklusif antara lain usia ( $p$ value : 0,293). Dari hasil penelitian, didapatkan sebagian besar responden $73 \%$ masuk dalam rentang usia reproduktif. Tetapi dari hasil penelitian didapatkan sebaran yang merata yaitu $45,5 \%$ yang berhasil memberikan ASI Eksklusif, 22,7\% yang memberikan ASI Predominan dan 31,8\% yang tidak memberikan ASI Ke bayinya. Sehingga usia bukan merupakan acuan seseorang dalam pemberian ASI Eksklusif. Faktor jenis pekerjaan didapatkan ( $p$ value : 0,297), dari hasil penelitian didapatkan sebagian besar responden $70 \%$ yang berperan sebagai Ibu Rumah Tangga tetapi hanya $33,3 \%$ yang berhasil memberikan ASI Eksklusif, 38,1\% memberikan ASI Predominan dan 28,6\% tidak memberikan ASI ke Bayinya.

Faktor pemberian informasi tentang ASI Eksklusif didapatkan $p$ value: 0,903, yang berarti tidak ada hubungan antara pemberian informasi tentang ASI dengan Keberhasilan pemberian ASI Eksklusif. Dari hasil penelitian diketahui sebanyak $57 \%$ responden tidak mendapatkan Informasi tentang ASI Eksklusif dan 43\% responden mendapatkan informasi tentang ASI Eksklusif, dari responden yang sudah mendapatkan informasi tentang ASI 
Eksklusif didapatkan 38,6\% yang berhasil memberikan ASI Eksklusif, 30,7\% memberikan ASI predominan dan 30,7\% yang tidak memberikan ASI Ke bayinya. Dukungan Keluarga ( $p$ value : 0,479) dan Dukungan dari Petugas Kesehatan ( $p$ value: $0,669)$, berarti tidak ada hubungannya dengan faktor keberhasilan pemberian ASI Eksklusif. Dari hasil penelitian didapatkan hampir seluruh responden $93 \%$ mendapatkan dukungan yang baik dari keluarga maupun petugas kesehatan, akan tetapi praktik pemberian ASI eksklusif utamanya dipengaruhi oleh faktor pendidikan dan pengetahuan yang dimiliki responden.

\section{KESIMPULAN}

Dari hasil penelitian ini didapatkan bahwa faktor-faktor yang ada hubungan signifikan dengan praktik pemberian ASI eksklusif adalah pendidikan ibu ( $p$ value: $0,037)$, informasi tentang cara menyusui ( $p$ value: 0,031), serta dukungan dari masyarakat ( $p$ value : 0,010). Sedangkan faktor - faktor yang tidak berhubungan dengan praktik pemberian ASI Eksklusif antara lain usia ( $p$ value : 0,293), jenis pekerjaan ( $p$ value : 0,297), pemberian informasi tentang ASI Eksklusif ( $p$ value: $0,903)$, Dukungan Keluarga ( $p$ value : $0,479)$, serta dukungan dari Petugas Kesehatan ( $p$ value: 0,669).

\section{SARAN}

Peningkatkan keberhasilan pemberian ASI Eksklusif, harusnya dilakukan penyuluhan ataupun konseling yang dimulai sejak kunjungan Ibu Hamil ke Petugas Kesehatan untuk periksa kehamilan yang bertujuan untuk memberikan persiapan informasi tentang persiapan menyusui, selanjutnya konseling ataupun penyuluhan akan dilanjutkan pada saat menyusui dimana bertujuan untuk pemantauan pemberian ASI Eksklusif sampai 6 bulan dan meningkatkan peran serta orang tua dalam kelompok pendukung ASI eksklusif.
Petugas Kesehatan diharapkan untuk meningkatkan kemampuan petugas kesehatan dalam memberikan penyuluhan yang efektif ke ibu untuk pemberian ASI eksklusif. Petugas kesehatan hendaknya memberikan penyuluhan ASI eksklusif sejak ibu hamil dengan bahasa yang aplikatif dan mudah dimengerti oleh Ibu menyusui.

\section{DAFTAR PUSTAKA}

Abdullah, S., D. Hastuti, U. Sumarwan, 2004, Pengambilan Keputusan Pemberian ASI Eksklusif kepada Bayi di Kota Bogor, Media GIZI \& KELUARGA, Juli 2004, hal. 70-77.

Anamed, 2013. Insufisient lactation. Anamed acupuncture. Diakses di website www.ana-med.co.nz

Anderson, McFarlane. 2008. Community as partner : theory and practice in nursing $5^{\text {th }}$ edition. Philadelphia : Lippincott Williams \& Wilkins

Biancuzzo, M. (2003). Breastfeeding the newborn: Clinical strategies for nurses. St. Louis: Mosby.

Binns, C., Scott, J (2002). Breastfeeding: Reason for starting, reason for stopping and problems along the way, Breastfeeding Review, Volume 10, No 2, pp 13-19.

Budioro, B., 1998, Pengantar Pendidikan (Penyuluhan) Kesehatan Masyarakat, Badan Penerbit Fakultas Kesehatan Masyarakat Universitas Diponegoro, Semarang, hal.12-20.

DepartemenKesehatan RI, 2001, Buku Panduan Manajemen Laktasi, Dit. Gizi Masyarakat- Depkes RI, Jakarta.

DepartemenKesehatan RI, 2004a, Kepmenkes RI No. 450/MENKES/IV/2004 tentang Pemberian Air Susu Ibu (ASI) secara Eksklusif pada Bayi Indonesia, DepartemenKesehatan RI, Jakarta. 
DepartemenKesehatan RI, 2004b, Kebijakan Departemen Kesehatan tentang Peningkatan Pemberian Air Susu Ibu (ASI) Pekerja Wanita, Departemen Kesehatan RI, Jakarta.

DepartemenKesehatan RI, 2005, Manajemen Laktasi: Buku Panduan bagi Bidan dan Petugas Kesehatan di Puskesmas, Dit. Gizi Masyarakat- Depkes RI, Jakarta.

Efendi, Mahfudli. 2007. Keperawatan Kesehatan Komunitas: Teori dan Praktik dalam keperawatan. Salemba Medika. Jakarta

Fikawati Sandra, 2010, Kajian Implementasi Dan Kebijakan Air Susu Ibu Eksklusif Dan Inisiasi Menyusu Dini Di Indonesia, Makara Kesehatan Vol 14, No1, Juni 2010:17-24

Hikmawati Isna, 2008, Faktor-Faktor Resiko Kegagalan Pemberian ASI Selama Dua Bulan (Studi Kasus pada bayi Umur 3-6 Bulan Di Kabupaten Banyumas, Tesis Universitas Diponegoro Semarang

IDAI, (2013). Kendala

Pemberian ASI

Eksklusif (diakses dari http://idai.or.id/publicarticles/klinik/asi/kendalapemberian-asi- eksklusif.html diunduh pada 12 November 2016).

King, F.S., 1991, Menolong Ibu Menyusui, PT. Gramedia Pustaka Utama, Jakarta, hal. 131-139.

King, F.S. dan A. Burgess, 1996, Nutrition for Developing Countries, $2{ }^{\text {nd }} E d$, Oxford University Press, New York, p. 96.

Kramer, M, Kakuma, R. (2002). The optimal Duration of Exclusive Breastfeeding. A systematic review, WHO, Switzerland.

LINKAGES, 2002, Pemberian ASI Eksklusifatau ASI saja: Satusatunya Sumber Cairan yang Dibutuhkan Bayi Usia Dini,
Diaksespadatanggal 10 Mei 2016, dariwww.linkagesproject.org.

Machfuddin, E, (2004). Refrat Patofisiologi Pembentukan ASI. Palembang: Departemen Obstetri dan Ginekologi Fakultas Kedokteran Universitas Sriwijaya.

Notoatmodjo, S., 2003, Prinsip-prinsip Dasar Ilmu Kesehatan Masyarakat, Penerbit Rineka Cipta, Jakarta, hal.118-145.

Nursalam, Pariani.S (2001). Pendekatan Praktis Metodologi Riset Keperawatan. Sagung seto. Jakarta

Prawirohardjo, Sarwono. 2002. Ilmu Kebidanan. Edisi ketiga. Jakarta: Yayasan Bina Pustaka Sarwono Prawirohardjo.

Pudjiadi, S., 2001, Bayiku Sayang: Petunjuk Bergambar untuk Merawat Bayi dan Jawaban atas 62 Pertanyaan yang Mencemaskan, Fakultas Kedokteran UI, Jakarta, hal. 16-33.

Pillitteri A. 2003. Maternal and Child Health Nursing. Philadelphia : Lippincott Williams and Wilkins

Riordan J \& Aurbach, K. G (2010). Breastfeeding and Human Lactation. London: Jones an barlett Publishers International

Roesli, U., 2005, Mengenal ASI Eksklusif, Trubus Agriwidya, Jakarta, hal. 247.

Roesli, U., 2001, Bayi Sehat berkat ASI Eksklusif, PT. Elex Media Komputindo, Jakarta, hal. 1-34.

Soetjiningsih, 1997, ASI Petunjuk untuk Tenaga Kesehatan, Penerbit Buku Kedokteran EGC, Jakarta, hal: 1175.

Suyatno, 2000, Pengaruh Pemberian Makanan Pendamping ASI (MPASI) Tradisional terhadap kejadian ISPA, Diare, dan Status Gizi Bayi pada 4 (empat) bulan Pertama Kehidupannya, Program PascasarjanaUniversitasGadjahMad a, hal. 35-68. 
ISSN Cetak 2303-1433

ISSN Online: 2579-7301

Tackett, K. (2007). A New Paradigm for Depression in new mothers: The Control role of Inflammation and low breastfeeding and antiinflammatory treatments protect maternal mental health. International Breastfeeding Journal, 2-6

Utomo, B., 2000, The Slowing Progress of Breastfeeding Promotion Program in Indonesia: Causes and
Recommendation, Kumpulan Makalah Diskusi Pakar bidang Gizi tentang ASI MP ASI, Antropometri, dan BBLR, Kerjasama antara Persatuan Ahli Gizi Indonesia, LIPI, dan UNICEF.

Wheller, L. 1997. Nurse-Midwifery Handbook: A Practical Guide To Prenatal and Postpartum Care. Philladelphia: Lippincott 